\title{
Flört Şiddetini Anlamak: Nitel Bir Çalışma
}

\author{
Duygu Eslek ${ }^{1}$ \\ Ege Üniversitesi
}

\author{
Rukiye K1z1ltepe ${ }^{2}$ \\ Ege Üniversitesi
}

\author{
Türkan Y1lmaz Irmak ${ }^{3}$ \\ Ege Üniversitesi
}

\begin{abstract}
Özet
Flört şiddeti son yıllarda önemli bir problem olarak dikkat çekmektedir. Türkiye'de de flört şiddetinin yaygın olduğu ve flört şiddetine maruz kalanların depresyon, intihar ve yeme bozukluğu gibi birçok psikolojik sorun deneyimlediği bilinmektedir. Bu nedenle, bu çalışmada nitel araştırma yöntemi kullanarak üniversite öğrencilerinin flört şiddeti ile ilgili düşüncelerini derinlemesine incelemek amaçlanmıştır. Odak grup görüşmeleri, bireylerin günlük yaşamda deneyimlediği veya yakın çevresinde sık karşılaştığı konular hakkında veri toplamayı amaçladığı için bu çalışmada odak grup görüşmeleri yürütülmüştür. Katılımcılar 78 üniversite öğrencisinden oluşmaktadır. Katılımcıların yaşları 18 ile $22($ Ort. $=19, S=1.2)$ arasında değişmektedir. Araştırmacılar tarafından katılımcıların flört şiddeti ile ilgili deneyimlerini, tutumlarını ve flört şiddeti tanımlarını incelemek için 10 soru oluşturulmuştur. Erkekler ve kadınlar için ayrı gruplarda sekiz odak grup görüşmesi yapılmıştır. Gruplar 8-13 katılımcıdan oluşmaktadır. Görüşmeler, bir görüşmeci ve bir gözlemci ile yürütülmüştür. $\mathrm{Bu}$ araşıırmada, verilerin değerlendirilmesi için içerik analizi kullanılmıştır. Her bir soru için katılımcıların cevapları iki araşıırmacı tarafından kodlanmış ve temalar belirlenmiş̧tir. Bu çalışmanın sonuçları katılımcıların duygusal flört şiddetine diğer flört şiddet türlerinden daha fazla örnek verdiğini göstermiştir. Katılımcıların flört şiddeti sonrasında arkadaşlarından ve ailelerinden destek almaları daha olasıdır. Ayrıca, katılımcılar flört şiddeti için bireysel, ailesel ve bağlamsal risk faktörlerini belirtmişlerdir. Çalışmanın diğer bulguları, bulgular bölümünde sunulmuş ve alanyazın ışığında tartışılmıştır.
\end{abstract}

Anahtar kelimeler: Flört şiddeti, üniversite öğrencileri, odak grup

\begin{abstract}
In recent years, dating violence has been recognized as an important problem. Researches showed that dating violence is prevalent, and victims experience many psychological problems such as depression, suicide, and eating disorders in Turkey. Therefore, this study aimed to examine thoroughly the thoughts of university students on dating violence by using a qualitative design. Focus group interviews were conducted in this study because these interviews aimed to collect data about subjects which individuals experience in daily life or frequently encountered in immediate surroundings. Participants consisted of 78 university students. The ages of the participants ranged from 18 to $22(M=19, S D=1.2)$. In total, ten questions have been developed by the researchers to examine experiences, attitudes, and definitions about dating violence. Eight focus group interviews were conducted in separate groups for male and female participants. The groups consisted of 8-13 participants. The interviews were conducted by one interviewer and one observer. In this study, content analysis was used to evaluate the data. The answers of the participants were coded and themes were determined for each question by two researchers. The results of this study showed that the participants gave more examples of psychological dating violence than other subtypes of dating violence. Participants were more likely to receive support from their friends and families following dating violence. Also, participants stated individual, familial, and contextual risk factors for dating violence. The other findings of this study were presented and discussed in light of the literature.
\end{abstract}

Keywords: Dating violence, university students, focus group

Yazar Notu: Bu çalışma Ege Üniversitesi Bilimsel Araştırma Projeleri Koordinasyon Birimi (18EDB012) tarafindan desteklenmiş ve Ege Üniversitesi Sosyal ve Beşerî Bilimler Bilimsel Araştırma ve Yayın Etiği Kurulu tarafindan 291-2017 protokol nolu karar ile 09.10.2017 tarihinde etik açıdan uygun bulunmuştur. Bu çalışmada odak grup görüşmeleri sırasındaki desteklerinden dolayı Arş. Gör. Dr. Cem Soylu'ya, Arş. Gör. Bahtım Kütük’e, Uzm. Psk. Sevgi Tunay Aytekin’e, Uzm. Psk. Zeynep Şen Hastaoğlu’na ve Dr. Öğr. Üyesi Durdane Gümüşten'e teşekkür ederiz.

Yazışma Adresi: ${ }^{1}$ Arş. Gör. Duygu Eslek, Ege Üniversitesi, Edebiyat Fakültesi, Psikoloji Bölümü, 35100 Bornova / İzmir, duygu. eslek@gmail.com, ORC-ID: 0000-0002-5649-2417

${ }^{2}$ Arş. Gör. Dr. Rukiye Kızıltepe, Ege Üniversitesi, Edebiyat Fakültesi, Psikoloji Bölümü, 35100 Bornova / İzmir, rukiyekiziltepe@gmail. com, ORC-ID: 0000-0001-8076-3419

${ }^{3}$ Doç. Dr. Türkan Y1lmaz Irmak, Ege Üniversitesi, Edebiyat Fakültesi, Psikoloji Bölümü, 35100 Bornova / İzmir, turkan.yilmaz.irmak@ ege.edu.tr, ORC-ID: 0000-0003-0777-7595

Gönderim Tarihi: 29.07 .2020

Kabul Tarihi: 05.05.2021 
Romantik ilişkiler kurmak çocukluktan yetişkinliğe geçiş döneminde başarılması gereken gelişimsel görevlerden biridir (Gander ve Gardiner, 2010). Flört davranışları da bu görevin gerektirdiklerindendir. Flört davranışının kimlik kazanımı, psikolojik iyi oluş ve yüksek benlik saygısı gibi olumlu sonuçları vardır (Ciairano vd., 2006; Erikson, 1950; McDonald ve McKinney, 1994; Samet ve Kelly, 1987). Bununla birlikte flörtün niteliği, şiddet içerip içermemesi de önemlidir (Ely, 2004). Flört şiddeti, romantik ilişki içinde bulunan kişi veya kişilerin birbirlerine fiziksel, sözel, cinsel, duygusal ve ekonomik olarak şiddet davranışlarında bulunması veya partnerinin hayatına yönelik sosyal kısıtlamalar getirmesi olarak tanımlanmaktadır (Polat, 2015). Flört şiddeti, fiziksel, duygusal, cinsel, ekonomik ve takip etme (stalking) olmak üzere beş grupta incelenmektedir. Fiziksel flört şiddeti; tokat atma, vurma, 1sırma, yumruk atma, tırmalama, tekme atma, silah kullanma ve itip kakma davranışlarını kapsar (Offenhauer ve Buchalter, 2011). Duygusal flört şiddeti; kişinin tehdit edilmesi, ona isim takılması, kasıtlı bir şekilde aşağılanması, utandırılması, aile ve arkadaşlarından uzaklaştırılması gibi davranışlarla açıklanır (Centers for Disease Control and Prevention [CDC], 2016). Cinsel flört şiddeti; kişinin cinsel aktiviteye zorlanmasıdır, fiziksel temas içerebilir veya içermeyebilir. Kişi hakkında dedikodu (cinsel konularda) yayma fiziksel temas içermeyen cinsel flört şiddetine örnek olarak verilebilir. Ekonomik şiddet, partnerin gelirine el koyma, bütçeyi tek başına planlama gibi davranışları içerir (World Health Organization [WHO], 2005). Takip ise kişinin istemediği, onu korkutan tehdit etme ve taciz etme davranışlarıdır (CDC, 2016).

Flört şiddeti alanyazında birçok kuram ile açıklanmaktadır. Feminist teoriye göre, cinsiyetler arasındaki güç eşitsizliğinden kaynaklanmaktadır (Follingstad vd., 1991). Sosyal öğrenme teorisine göre ise şiddet uygulayan ebeveynin rol model alınması kaynaklı oluşmaktadır (Riggs ve O'Leary, 1989). Flört şiddeti her sosyoekonomik seviye ve etnik grupta görülen bir olgudur. Toplumun flört şiddetini ilişkinin doğal bir parçası olarak görmesi de şiddeti arttıran ve meşrulaştıran bir unsur olarak değerlendirilmektedir (O'Keefe ve Treister, 1988). Flört şiddetinin tanımı, çeşitleri, kuramsal açıklamalarının sonrasında flört şiddetinin toplumdaki yaygınlığını incelemek önem taşımaktadır.

\section{Flört Şiddetinin Yaygınlığı}

Şiddet konusunda yapılan araştırmalar, flört ilişkilerinde yaşanan şiddetin en az evlilikte yaşanan şiddet kadar yaygın olduğunu göstermektedir (Makepeace, 1981; Roscoe ve Bemaske, 1985). Sugarman ve Hotaling'in (1989) çalışmasına göre üniversite örnekleminde flört ilişkisinde şiddetle karşılaşma oranının evlilik ile benzer şekilde yaklaşık \%30 olduğu görülmektedir.

Üniversite öğrencilerinde flört şiddetinin yaygınlığ1 incelendiğinde, 18-25 yaş aralığındaki 863 kadınla yapılan çalışmada, bir defa flört şiddetine uğrayanların oran $1 \% 48$ iken, birden fazla flört şiddetine uğradı̆̆ını belirtenlerin oranı \%39'dur (Amar ve Gennaro, 2005). Üniversiteye devam eden kadınlarla yapılan bir diğer çalışmada, katılımcıların \%7'si sadece maruz kalan, $\% 43.3$ 'ü sadece fail, $\% 72.8$ 'i ise hem maruz kalan hem fail olduklarını belirtmişlerdir (Kaukinen vd., 2012).

Flört şiddeti ile ilgili ilk çalışma olan, Makepeace'in (1981) çalışmasında, kadınların \%92'si $(n=22)$, erkeklerin \%31'i $(n=4)$ flört şiddetine maruz kaldıklarını belirtmişlerdir. Her ne kadar bu çalışmada kadınların erkeklerden daha fazla flört şiddetine maruz kaldığ 1 görülse de Follette ve Alexander (1992) tarafindan 100 çiftin değerlendirildiği bir başka çalışmada, kadın ve erkeklerin flört şiddetine uğrama oranları arasında anlamlı bir fark bulunmamıştır. Birçok çalışmada flört şiddetine maruz kalma oranının cinsiyete göre farklılaşmadığ 1 desteklenmiştir (Laner ve Thompson, 1982; Stets ve Pirog-Good, 1987; Sugarman ve Hotaling, 1989). O'Keefe ve Treister, (1988) tarafindan 14-20 yaş aralığında 385 erkek ve 554 kadın olmak üzere toplamda 939 katılımcı ile gerçekleştirilen çalışmada maruz kalma bakımından değerlendirilen flört şiddetinin yaygınlığının cinsiyete göre farklılaşmadığ 1 bulunmuştur. Ancak, erkekler daha çok fiziksel flört şiddetine kadınlar ise daha çok cinsel flört şiddetine maruz kalmaktadırlar. Araştırmacılar erkeklerin fiziksel şiddete sıklıkla maruz kaldıklarını ancak bunu fiziksel güç farklılığı nedeniyle önemsemediklerini belirtmişlerdir. Bu bulgunun örnekleme özgü olabileceği de düşünülmüştür. Ülkemizde yapılan çalışmalar incelendiğinde, 700 kadın üniversite öğrencisi ile yapılan bir çalışmada katılımcıların \%84'ünün cinsel flört şiddeti deneyimledikleri bulgulanmıştır (Kayı vd., 2000). Toplu ve Hatipoğlu-Sümer (2011) tarafindan 834 üniversite öğrencisi ile yapılan çalışmada ise kadınların \%46's1, erkeklerin \%35'i fiziksel flört şiddetine maruz kaldığını belirtmiştir. Ayrıca kadınlarda duygusal flört şiddetine maruz kalma oranı \%85 iken erkeklerde $\% 76$ olarak bulunmuştur. Flört şiddetinin yaygınlığının ve cinsiyete göre değişimlerin incelenmesinin yanı sıra flört şiddetine sebep olabilecek risk faktörlerinin de ayrıntılı incelenmesi önemlidir.

\section{Flört Şiddetinin Risk Faktörleri}

Cicchetti ve Lynch (1993) tarafından geliştirilen Ekolojik/Etkileşimsel Model şiddet yaşantılarının değerlendirilmesinde bireysel, ailesel ve toplumsal faktörlere vurgu yapmaktadır. Bu çalışma kapsamında da risk faktörleri bireysel, ailesel ve toplumsal olmak üzere üç kategoride incelenecektir. 
Bireysel risk faktörleri. Flört şiddetine maruz kalan kişilerin, ilişki doyumu düşük, fazla partner değiştiren, düşük özsaygılı bireyler oldukları belirtilmektedir (Ackard ve Neurmark-Sztainer, 2002; O'Keefe ve Treister, 1988). Öfke, depresyon gibi sorunlar flört şiddetinin nedeni olabildiği gibi sonucu da olabilmektedirler (O’Keefe, 2005). Alkol ve madde kullanımının, flört şiddetinin en yaygın görülen risk faktörü olduğu belirtilmektedir (Harned, 2002; Rothman vd., 2012; Swahn vd., 2008). Van Ouytsel ve arkadaşları (2017) tarafindan yürütülen çalışmada, flört şiddetine maruz kalma oranlarının erken yaşta esrar ve alkol kullanımı ile arttığ bulgulanmıştır. Benzer şekilde, alkol kullanımı gençler arasında flört şiddetine maruz kalmayı ve şiddeti destekleyici davranışlarda bulunmayı arttırmaktadır (Mulawa vd., 2018; Parker vd., 2016). Ayrıca, cinsel risk alma davranışları da kişiyi flört şiddetine açık hale getirebilmektedir (Kaukinen, 2014).

Bireysel risk faktörlerinden, akranların etkisi özellikle saldırgan davranışlar üzerinde oldukça etkilidir (Harris, 1995). Üniversite öğrencileri ile yapılan bir çalışmada, flört şiddeti uygulayan akranların olması ile flört şiddetine maruz kalma arasında pozitif yönlü bir ilişki olduğu ortaya koyulmaktadır. Ayrıca akranlardan soyutlanmak da flört şiddeti riskini arttırmaktadır (Gwartney-Gibbs vd., 1987).

Şiddete maruz kalan kişilerin daha sonraki ilişkilerinde de bu döngüyü kıramayıp şiddet deneyimledikleri belirtilmektedir (Noland vd., 2004). Çocukken istismara maruz kalanların büyük bir oranı ergenlik ve genç yetişkinlikte flört şiddetine, evlendiklerinde ise aile içi şiddete maruz kalmaktadır. Bunun nedeninin kişilerin şiddet türleri için risk faktörlerinin çoğuna sahip olması olduğu belirtilmektedir (O'Keefe ve Treister, 1988).

Leisring'in (2013) üniversiteli kadınlarla yaptığ bir çalışmada öfke, duygusal incinmenin intikamı, partnerin ilgisini çekme, kıskançlık ve stresin flört şiddeti uygulama için risk faktörü olduğu belirtilmiştir. Bazen kadınlar kendini korumak için de şiddet davranışı gösterebilmektedirler. Farklı bir çalışmada ise kadın ve erkek faillerin flört şiddeti uygularken benzer risk faktörlerine sahip olduğu belirtilmiştir (O’Keefe ve Treister, 1998).

Ailesel risk faktörleri. Aile içerisinde şiddete maruz kalan bireylerin, model aldıkları bu davranışları yetişkinlikte de sürdürmeye yatkın oldukları belirtilmiştir (O’Keefe, 2005). Çocuklar aile içinde şiddete maruz kaldıklarında, yetişkinlik döneminde daha fazla saldırganlık davranış1 gösterebilmektedirler (Cüceloğlu, 1991). Benzer biçimde, çocukluk döneminde ebeveynleri tarafindan cezalandırılan (Temple vd., 2018) ve ihmal edilen (Earnest ve Brady, 2016) çocuklarda da flört şiddetinin varlığı bilinmektedir. Çocukluk döneminde cinsel şiddete maruz kalmış erkeklerin cinsel şiddet uygulama oran- larının daha fazla olduğu bulgulanmıştır (Debowska vd., 2017). Başka bir çalışmada ise, genç kadınlarda şiddete maruz kalma veya şiddet uygulama olasılıkları ile aile içi şiddete maruz kalma dereceleri arasında pozitif bir ilişki olduğu bulunmuştur (Choi ve Temple, 2016).

Bağlamsal risk faktörleri. Bağlamsal risk faktörleri arasında kültürel yap1 ve cinsiyet rollerine yüklenen anlamlar gibi daha geniş bağlamın rolü incelenmektedir (Reidy vd., 2015; White ve Kowalski, 1993). Ülkemizde yaygın olarak görülen kadına yönelik şiddet konusunda, erkeklerin kadınları kontrol etme isteği, bask1 kurma, cezalandırma ve güç gösterisinde bulunma isteği gibi faktörlerin rolü olduğu belirtilmektedir (Page ve İnce, 2008). Ataerkil aile yapısı, kadınların çevreden izole edilmesi ve cinsiyetler arasında eğitim eşitsizliğinin olmasının toplum düzeyinde şiddet riskini arttırdı $\breve{g}_{1}$ bilinmektedir (Heise, 1998). Dünya Sağlık Örgütü'nün raporuna göre, erkeklerin otonomisinin kadınlardan yüksek olduğu, kadınların düşük eğitim seviyesine sahip olduğu, işsizlik ve yoksulluk oranının yüksek olduğu toplumlarda flört şiddeti daha s1k görülebilmektedir (WHO, 2002). Yine aynı rapora göre, cinsiyet temelli normların artması ile birlikte (örneğin, kadınlığın pasiflik ve boyun eğme, erkekliğin ise hakimiyet ile ilişkilendirilmesi) toplum düzeyinde şiddetin arttığı da görülmektedir. Erkeğin sözünü emir olarak algılayan kadınların şiddeti daha kolay kabul ettikleri bulgulanmıştır. Benzer şekilde, geleneksel ataerkil yapıyı benimseyen erkeklerin de şiddeti ilişkinin normal bir unsuru olarak değerlendirme eğiliminde oldukları bilinmektedir (Gressard vd., 2015). Kişinin sosyal çevresinin şiddeti meşrulaştırmas1 da şiddetin yaygınlaşmasını pekiştirmektedir (Heise, 1998). Flört şiddetinin risk faktörlerinin yanı sıra flört şiddetinin olumsuz sonuçları da kişilerin hayatını geniş kapsamda etkilemektedir.

\section{Flört Şiddetinin Sonuçları}

Flört şiddetine maruz kalan kişiler birçok sorunla karşılaşmaktadırlar. Flört şiddetine maruz kalan kişilerin suçluluk, öfke, kaygı ve düşük benlik saygısı bildirdikleri bilinmektedir (Makepeace, 1981; Smith ve Donnelly, 2001). İlgili çalışmalar incelendiğinde flört şiddetinin depresyon ve kayg1 düzeyinin (Callahan vd., 2003), sigara ve madde kullanımının (Ackard vd., 2007), intihar düşünceleri ve girişimlerinin (Baker vd., 2015; Olshen vd., 2007) ve yeme bozukluklarının (Ackard ve Neumark-Sztainer, 2002) artmasına sebep olabileceği belirtilmektedir. Dikmen ve arkadaşlarının (2018) üniversite öğrencisi kadınlar ile gerçekleştirdikleri çalışmada, flört şiddeti yaşayan kadınların kaygı düzeyinin daha yüksek olduğu görülmüştür. Başka bir çalışmada flört şiddetinin duygusal iyilik halinin azalmasıyla ilişkili olduğu belirtilmiştir (Ackard ve Neumark-Sztainer, 2002). Bunlara 
ek olarak şiddet içeren bir ilişki içerisinde bulunmanın, kadınların kondom kullanmadan cinsel ilişkiye girme gibi riskli cinsel davranışlarının artışına yol açtığı da bilinmektedir (Kaukinen, 2014; Rizzo vd., 2020). Flört şiddetinin, ileri dönemlerde evlilik içi şiddetin bir öncülü olabileceğine dair de sonuçlar bulunmaktadır (Frieze, 2000; Smith ve Donnelly, 2001). Bu bulgu şiddet döngüsünü desteklemektedir.

Flört şiddetinin üniversite öğrencileri arasında yaygın görülen ve olumsuz sonuçları olan bir sorun olduğu görülmektedir. Alanyazında flört şiddetinin derinlemesine incelenmesi niteliksel çalışmalarla gerçekleştirilmiştir. 11-13 yaş arasındaki ergenlerle cinsiyetlere göre ayrılarak yapılan çalışmada, katılımcıların cevaplarının; saygı veya saygısızlık, arkadaşların etkisi, cinsel birleşmenin bedeli veya faydası, kabul edilebilir bir tepki olarak şiddet olmak üzere dört temada yoğunlaştığı belirtilmiştir (Fredland vd., 2005). Bir diğer çalışmada 14-22 yaş aralığındaki gençler ile odak gruplar gerçekleştirilmiştir. Bu gruplarda katılımcıların, flört şiddeti dışındaki şiddet yaşantılarından, erkeklerin şiddeti bir güç gösterisi olarak algıladığından ve kadınların şiddeti bir bağlılık göstergesi olarak gördüklerinden bahsettiği belirtilmiştir (Johnson vd., 2005). Görüldügüü üzere, birçok farklı yaş grupları ile niteliksel çalışmalar gerçekleştirilmiş ve katılımcıların cevaplarına dair çeşitli temalar oluşturulmuştur. Türkiye'de yapılan, Fidan ve Yeşil'in (2018) çalışmasında 30 şiddet uygulayan erkek ve 30 şiddete maruz kalan kadın üniversite öğrencisiyle bireysel görüşme, cinsiyete göre bölünmüş odak grup görüşmeleri ve iki cinsiyetin de bulunduğu odak grup görüșmeleri yapılmıştır. Şiddete neden olan düşünce yapısının; flört ilişkisinin "sahip olma" ve "sahiplenme" kavramları ile tanımlanması olduğu belirtilmiştir. Bireyler flört ilişkisini sahiplenme olarak algıladıkları için, dışarıdan gelen flört şiddetini önleme veya sonlandırmaya yönelik müdahaleleri olumsuz algılamakta ve ilişkiyi sürdürme eğiliminde olmaktadırlar. Erkekler flört şiddetini sahiplenme davranışı olarak değerlendirmektedir. Kadınlar, şiddeti sosyal çevre, partnerin karakteri ve kendi tutumları temelinde normalleştirmektedir. $\mathrm{Bu}$ da şiddetin devam etmesine neden olmaktadır. Bir diğer niteliksel araştırma olan Çimen'in (2018) çalışmasında ise 18-30 yaşlarında kadın ve erkekler ile bireysel görüşmeler yapılmıştır. Söylem analizi sonuçlarına göre, partnerlerin karş1lıklı rol, sorumluluk ve beklentilerinin oluşmasında toplumsal cinsiyet normlarının belirleyici olduğu belirtilmiştir. İlişkilerde beklentilerin uyumsuzluğunun, flört şiddetine zemin hazırladığ1 ve partnerlerin olumlu duygularını sorgulamasına neden olduğu bulunmuştur. Katılımcılar flört şiddetini; insanın biyolojik temeli veya "sevgi" ifadesi olarak açıklamakta ve şiddeti olağanlaştırmaktadırlar. Bunun yanı sıra ilişkilerinde şiddetin var olmadığını dü- şünmektedirler. Özetle iki çalışmada da benzer sonuçlara varıldığ1 görülmektedir.

Alanyazından da görüldüğü üzere, flört şiddetinin üniversite öğrencileri üzerinde kısa ya da uzun süreli birçok olumsuz etkisi bulunmaktadır. Ülkemiz sosyal ve kültürel bağlamında bu konunun derinlemesine incelenmesinin ve flört şiddetine ortam sağlayan bireysel, ailesel ve bağlamsal ögelerin saptanmasının gerekli olduğu düşünülmektedir. Bu nedenle flört şiddeti hakkında derinlemesine bilgi edinebilmek için niteliksel bir araştırmanın yapılmasına gerek duyulmuştur. Bu çalışmada üniversite öğrencisi kadın ve erkeklerden flört şiddeti hakkındaki düşünceleri, tutumları ve algıları ile ilgili bilgi almak amaçlanmaktadır.

\section{Yöntem}

Üniversite öğrencilerinin flört şiddeti ile ilgili algılarını derinlemesine incelemeyi amaçlayan bu araştırmada nitel araştırma yöntemi kullanılmıştır. Nitel araştırmalar, bir olguyu tanımlamayı, incelemeyi ve anlamayı amaçlamaktadır. Ayrıca deneyimlenen durumlar hakkında kişilerin kendi duygu, düşünce ve algılarını bize öznel olarak sunma olanağı tanımaktadır (Baltacı, 2019; Y1ldırım ve Şimşek, 2013). Araştırmada odak grup görüşmesi ile veri toplanmıştır. Odak grup yönteminin seçilmesinin bazı avantajları bulunmaktadır. Bireysel görüşmelerde şiddet gibi konular hakkında konuşmak katılımcılar için zor olabilir, katılımcılar görüşmeciye gerçek duygu ve düşüncelerini yansıtmakta ve kendini açmakta zorlanabilirler. Ancak odak grup görüşmelerinde, gruptaki kendini daha kolay açabilen katılımcılardan biri diğerleri için de yol gösterici olur ve diğer katılımcıların kendilerini daha rahat açmaları için cesaret verir. Benzer deneyim ve düşüncelere sahip olan kişilerin bulunduğu bir ortam katılımcılara güven sağlar (Krueger ve Casey, 2015).

\section{Örneklem}

Araştırmaya Ege Üniversitesi Edebiyat Fakültesi ve Diş Hekimliği Fakültesi'nde öğrenim görmekte olan 78 üniversite öğrencisi katılmıştır. Katılımcıların \%56's1 $(n=44)$ kadın, \%44'ü $(n=34)$ erkektir. Katılımcıların yaşları 18 ile $22($ Ort. $=19, S=1.2)$ arasında değişmektedir. Katılımcıların, \%38'i $(n=30)$ Sosyoloji, \%30'u $(n=$ 23) Felsefe, $\% 5$ 'i $(n=4)$ İngiliz Dili ve Edebiyatı, $\% 3$ ü $(n=2)$ Psikoloji, \%3'ü $(n=2)$ Coğrafya, \%1'i $(n=1)$ Mütercim Tercümanlık, $\% 1$ 'i $(n=1)$ Türk Dili ve Edebiyatı, \%1'i $(n=1)$ Tarih ve \%18'i $(n=14)$ Diş Hekimliği bölümlerine devam etmektedir.

\section{Veri Toplama Araçları}

Katılımcıların flört şiddetine yönelik algı, deneyim 
ve tutumlarını incelemek amacıyla araştırmacılar tarafindan açık uçlu sorular oluşturulmuştur. Araştırma kapsamında hazırlanan sorular flört şiddeti tanımları, flört şiddeti çeşitleri, şiddetin nedenleri, flört şiddetine maruz kalan ve fail olan kişilerin özellikleri, flört şiddeti ile baş etme yöntemleri ve flört şiddetini önleme yöntemleri konularını kapsamaktadır.

\section{İşlem ve Veri Analizi}

Araştırmanın etik kurul izni 09.10.2017 tarihinde Ege Üniversitesi Sosyal ve Beşeri Bilimler Bilimsel Araştırma ve Yayın Etiği Kurulu'ndan (Protokol no: 291-2017) alınmıştır. Etik kurul izninin ardından Ege Üniversitesi Edebiyat Fakültesi ve Diş Hekimliği Fakültesi'nde bulunan öğrencilerin çalışmaya katılması için derslerinin öğretim üyelerinden gerekli izinler alınmış ve çalışmanın duyurusu yapılmıştır. Çalışmaya gönüllü olarak katılmak isteyen öğrenciler belirlendikten sonra ögrencilere uygun olan saatte odak grup görüşmesi için randevu verilmiştir.

Görüşmeler her bir grupta bir görüşmeci ve bir gözlemci olmak üzere dört doktora öğrencisi tarafindan yürütülmüştür. Kadın ve erkek öğrenciler için ayrı gruplar oluşturulmuş, kadın görüşmeciler kadınlardan oluşan grupları yönetirken, erkek görüşmeciler erkeklerden oluşan grupları yönetmiștir. Katılımcılara araştırmanın amacı anlatıldıktan sonra yazılı onamları alınmıştır. Toplam 8 odak grup görüşmesi yapılmıştır. Odak grup görüşmeleri 40 ile 90 dakika arasında sürmüştür. Kat1lımcıların izni alınarak görüşmelerde ses kaydı alınmıştır. Kimliklerin gizliliğini korumak amacıyla ses kayıtlarında katılımcıların isimleri yerine katılımcılara verilen numaralar kullanılmıştır.

$\mathrm{Bu}$ çalışma kapsamında odak grup görüşmeleri aracılığıyla elde edilen verilerin analizi için içerik analizi kullanılmıştır. İçerik analizinde iki temel işlem bulunmaktadır: ilk olarak analitik betimleme ve kodlama ikinci olarak çıkarım işlemi yapılır (Bilgin, 2000). Diğer bir deyişle, içerik analizinde birbirine benzeyen söylem ve veriler, temalara göre ayrılır ve okuyucunun daha iyi anlamlandırması için düzenlenir (Yıldırım ve Şimşek, 2013). Bu çalışma kapsamında da ilk olarak ses kaydı ile kaydedilen tüm görüşmeler deşifre edilmiştir. Her görüşme için belirlenen temalar doğrultusunda ortak görüşler bir araya getirilerek iki araştırmacı tarafından kodlanmıştır. Kodlar daha üst temaların altında bir araya getirilmiştir. Araştırmacılar tarafından alanyazın göz önünde bulundurularak oluşturulan temalardaki söylemler frekans ile sunulmuş ve daha iyi anlaş1labilmesi bakımından katılımcıların örnek söylemleri bulgular kısmında verilmiştir.

Bu çalışma kapsamında kodlama iki araştırmacı tarafından gerçekleştirilmiştir. Kodlayıcılar arası güvenir- lik .98 olarak saptanmıştır. Ayrıca bu çalışma kapsamında katılımcıların sekizinci soruya verdikleri yanıtlar iki araştırmacı tarafından etkili ve etkisiz olarak kodlanmıştır. Bu kodlama işlemi için de kodlayıcılar arası güvenirlik .90 olarak bulunmuştur. İki söylem için kodlayıcılar arası uyuşmazlık olduğu saptanmış ve araştırmacılar bu iki ifade için ortak bir karar vermişlerdir.

\section{Bulgular}

Araştırmada katılımcıların görüşme sorularına verdikleri yanıtlara içerik analizi yapılmıştır. Katılımcıların görüşme sorularına derinlemesine cevap verdiği durumlarda katılımcıların ifadelerinin sayısı örneklemdeki katılımcı sayısını $(n=78)$ aşabilmektedir. Araştırmanın ilk sorusu katılımcıların flört şiddeti tanımlamalarına ilişkin değerlendirmeleridir. Ancak katılımcılar tanımdan ziyade flört şiddeti davranışlarını örneklendirmiştir. Bu nedenle az sayıda $(n=22)$ tanım üretilmiştir. Bu tanımlar: "Karşıdaki kişinin onayı olmayan her şey, karşı tarafı strese sokabilecek herhangi bir şey, karşıllklı isteklere cevap verememe, daha çok seven tarafin sevgisinin suistimal edilmesi vb.” şeklinde örneklendirilebilir. Çalışmanın ikinci ve üçüncü soruları birlikte değerlendirilmiştir. Bunlar: "Hoşlandığınız kişi tarafından yapılan ve sizi rahatsız ve korkmuş hissettirecek davranışları anlatır mısınız? Hoşlandığınız kişiye yaptığınız onu rahatsız ve korkmuş hissettirecek davranışları anlatır mısınız?’. Bu sorulara verilen yanıtlar flört şiddeti çeşitleri temelinde; fiziksel, duygusal, cinsel, ekonomik şiddet ve takip olmak üzere 5 kategoride toplanmıştır. Katılımcıların ifadelerinin \%72'si $(f=187)$ duygusal, \%17'si $(f=45)$ cinsel, \%9'u $(f=22)$ fiziksel, $\% 1$ 'i $(f=3)$ takip etme ve $\% 1$ 'i $(f=2)$ ekonomik şiddet kategorileri ile ilgilidir.

Şiddet türlerine ilişkin alt kategoriler de her tür için ayrı ayrı sunulacaktır. Takip etme ve ekonomik şiddetin alt kategorileri olmadığı için bu iki çeşit ayrı olarak sunulmayacaktır. Fiziksel şiddete ilişkin 2 alt kategori belirlenmiştir. Bunlar, fiziksel temas ve eşya kullanmadır. Duygusal flört şiddeti 17 alt kategoride sunulmaktadır. Bunlar; zorlama/hakimiyet kurma, özel alanı kısıtlama, hakaret etme, aşağılama, kıskançlık, manipülasyon, bağırma, yok sayma, gelecek planlarından bahsetme, tutarsiz davranma, sanal ortamda kisitlama, saygisız davranma, kararlarını sadece kendini düşünerek alma, aldatma, kıyas yapma, kıskandırma ve zorbalıktır. Bu alt kategorilere ek olarak, bazı katılımcılar duygusal flört şiddetinin azımsandığını, şiddetin sadece fiziksel değil duygusal da olabileceğini $(f=10)$ vurgulamışlardır. Cinsel şiddete ilişkin 3 alt kategori bulunmaktadır. Bunlar; fiziksel temas içeren davranışlar, fiziksel temas içermeyen davranışlar ve cinsel şiddete ortam hazırlamadır. Buna ek olarak, flört şiddeti olarak sınıflandırılmayan, kadınla- 
Tablo 1. Fiziksel, Duygusal ve Cinsel Şiddetin Alt Kategorileri

\begin{tabular}{|c|c|c|c|}
\hline Kategoriler & $f$ & $\%$ & Katılımcı söylemleri \\
\hline \multicolumn{4}{|l|}{ Fiziksel Şiddet } \\
\hline Fiziksel temas & 17 & 77 & Tokat, tekme, boğazını sıkma, tokat bile şiddettir \\
\hline Eşya kullanma & 5 & 23 & Eşya firlatmak, boğazına bıçak dayamak \\
\hline Toplam & 22 & 100 & \\
\hline \multicolumn{4}{|l|}{ Cinsel Şiddet } \\
\hline Fiziksel temas içeren & 27 & 63 & Taciz, tecavüz, istemediği halde öpmeye çalışmak, sıkıştırmak \\
\hline Fiziksel temas içermeyen & 12 & 28 & Mini etekli birine laf atma, fotoğraf göndermek, fotoğraf istemek \\
\hline $\begin{array}{l}\text { Cinsel şiddete ortam hazırlamak } \\
\text { (grooming) }\end{array}$ & 4 & 9 & Yavaş yavaş kandırmaya çalışıyorlar, adım adım ilerliyor, sürekli eve çağırmak \\
\hline Toplam & 43 & 100 & \\
\hline \multicolumn{4}{|l|}{ Duygusal Şiddet } \\
\hline Zorlama/hakimiyet kurma & 29 & 16 & İstemediği şeyleri yaptırmak, duygusal baskı, baskın olma \\
\hline Özel alanı kısıtlama & 26 & 14 & Bireyselliği kısıtlama, her gün görüşmek isteme \\
\hline Hakaret etme & 18 & 10 & Küfür etme, lakap takma, bir söz üzerinden incitmek \\
\hline Aşağılama & 17 & 9 & Değersizleştirme, küçük düşürmek, alay etmek, küçümsemek \\
\hline Kıskançlık & 16 & 9 & Kıyafete karışma, karşı cinsten arkadaşlara karışma \\
\hline Manipülasyon & 12 & 7 & Soğuk davranma, trip atmak, terk etmekle tehdit etmek \\
\hline Bağırma & 11 & 6 & Yüksek ses tonu ile konuşmak, bağırmak, azarlamak \\
\hline Yok sayma & 11 & 6 & $\begin{array}{l}\text { Görmezden gelme, kolay vazgeçme, karşı tarafın önemsediği şeyi } \\
\text { önemsememek }\end{array}$ \\
\hline Gelecek planlarından bahsetmek & 7 & 4 & $\begin{array}{l}\text { Evlilik istiyorum, çocuk istiyorum demek, flörtün ilk zamanlarında aileyle } \\
\text { tanışmak istemek }\end{array}$ \\
\hline Tutarsız davranma & 7 & 4 & İkiyüzlü davranması, zor zamanlarında yanında olmamak \\
\hline Sanal ortamda kisitlama & 6 & 4 & Şifre isteme, arkadaşları silme, engelleme \\
\hline Saygisız davranma & 6 & 4 & Düşüncelerine kararlarına saygı duymama, karşısındakini dinlememek \\
\hline $\begin{array}{l}\text { Kararlarını sadece kendini } \\
\text { düşünerek alma }\end{array}$ & 4 & 2 & Kendini merkeze koyarak davranma, bencillik, benmerkezcilik \\
\hline Zorbalık & 3 & 2 & Cezalandırma, kısasa kısas yapma \\
\hline Aldatma & 2 & 1 & Başkalarıyla konuşmak \\
\hline Kıyas yapma & 2 & 1 & Başkalarının sevgilileri yapıyor sen niye yapmıyorsun deme \\
\hline Kıskandırma & 2 & 1 & Başkalarını kullanarak kıskandırma \\
\hline Toplam & 179 & 100 & \\
\hline
\end{tabular}

rın cinsel ilişki sırasında son anda vazgeçmesi $(f=2)$ katılımcılar tarafından cinsel flört şiddeti olarak tanımlanmıştır. Ancak bu kadınların kendi isteklerinin ifadesi olarak değerlendirildiğinden bu çalışma kapsamında flört şiddeti olarak sınıflandırılmamıştır. Alt kategorilere ve analizlere ilișkin sonuçlar Tablo 1'de sunulmuştur.

Araştırmanın dördüncü sorusu olan "İlişsinizde ya da tanık olduğunuz ilişkilerde flört şiddeti uygulayan kişileri nasıl tanımlarsınız? Bu kişilerin özellikleri için neler söyleyebilirsiniz?" sorusu için katılımcıların cevaplarına göre faillerin özellikleri belirlenmiştir. Faile dair olan söylemler bireysel, ailesel ve bağlamsal olmak üzere üç kategoride incelenmiştir. Katılımcıların yanıtlarının \%77'sinin $(f=114)$ bireysel, \%14'ünün $(f=20)$ ailesel, \%9'unun $(f=14)$ bağlamsal açıklamalar içerdiği görülmüştür. Çalışmanın beşinci sorusu olan "Sizin ilişkinizde veya tanık olduğunuz ilişkilerde flört şiddetine uğrayan kişiler için neler söyleyebilirsiniz?” ile katılım- 
Tablo 2. Failin ve Maruz Kalanın Özellikleri

\begin{tabular}{|c|c|c|c|}
\hline Kategoriler & $f$ & $\%$ & Katılımcıların söylemleri \\
\hline \multicolumn{4}{|l|}{ Fail } \\
\hline Bireysel & 114 & 77 & Bencil, öfkeli, güvensiz, psikolojisi bozuk, saldırgan, sınırlarını bilmeyen, sahiplenici, kıskanç \\
\hline Ailesel & 20 & 14 & İyi aile eğitimi almamış, aile içi şiddet yaşama, parçalanmış aile, ihmalkâr ebeveynler \\
\hline Bağlamsal & 14 & 9 & Sosyal medya, toplumsal cinsiyet eşitsizliği, çevre baskısı, ataerkil toplum, atasözleri \\
\hline Toplam & 148 & 100 & \\
\hline \multicolumn{4}{|c|}{ Maruz Kalan } \\
\hline Bireysel & 110 & 85 & $\begin{array}{l}\text { Bağımlı, özgüvensiz, korkak, güçsüz, pasif, sevgiye aç, psikolojik sorunları olan, duygusal, } \\
\text { karşı koyma becerileri az, partnerini kışkırtmıştır, hak etmiştir }\end{array}$ \\
\hline Ailesel & 4 & 3 & Aile içi şiddet yaşama, baba sevgisi görmemiş \\
\hline Bağlamsal & 16 & 12 & Küçük yerde yaşayan \\
\hline Toplam & 130 & 100 & \\
\hline
\end{tabular}

cıların cevaplarına göre maruz kalanların özellikleri belirlenmiştir. Maruz kalanların özellikleri, bireysel, ailesel ve bağlamsal olmak üzere 3 kategoride incelenmiştir. Katılımc1ların ifadelerinin $\% 85$ 'i $(f=98)$ bireysel, $\% 4$ 'ü $(f=4)$ ailesel ve $\% 12$ 'si $(f=16)$ bağlamsal kategorilere dahil edilmiştir. Bunların yanı sıra bazı katılımcılar herkesin şiddete maruz kalabileceğini, maruz kalanların spesifik özelliklerinin olmadığını $(f=2)$ belirtmişlerdir. Analiz sonuçları ve kategorilere ilişkin değerler Tablo 2'de sunulmaktadır.

Araştırmanın altıncı sorusu olan "Flört şiddeti davranışına maruz kaldığınızda neler yaptınız?” Eğer kalırsanız neler yaparsınız?" sorusuna cevap olarak katılımcılar flört şiddetine maruz kaldıktan sonra yapılabileceklere dair çözüm önerileri üretmişlerdir. Flört şiddetine maruz kalındıktan sonra bulunan çözüm önerileri bir şey yapmama, ilişkiyi sonlandırma, şiddetin yoğunluğuna bağlı olarak karar verme, sorunu çözmek için eyleme geçme, aynısını faile yapma, şikâyet etme ve duygusal tepki verme olmak üzere 7 kategoride incelenmiştir. Bu kısımda frekansın örneklem sayısından $(n=78)$ düşük çıkmasının nedeni birine anlatma seçeneği başka soruda değerlendirildiği için burada belirtilmemiş olmasıdır. Katılımcıların cevaplarının \%28'i $(f=18)$ bir şey yapmama, \%25'i $(f=16)$ ilişkiyi sonlandırma, \%22'si $(f=14)$ şiddetin yoğunluğuna bağlı olarak karar verme, $\% 11$ 'i $(f=7)$ sorunu çözmek için eyleme geçme, \%9'u $(f=6)$ aynısını faile yapma, \%3'ü $(f=18)$ şikâyet etme ve $\% 2$ 'si $(f=1)$ duygusal tepki verme kategorilerinde bulunmaktadır. Kategorilere ve analiz sonuçlarına dair

Tablo 3. Flört Şiddetine Maruz Kalındıktan Sonraki Sürece Dair Çözüm Önerileri

\begin{tabular}{|c|c|c|c|}
\hline Kategoriler & $f$ & $\%$ & Katılımcıların söylemleri \\
\hline Bir şey yapmama & 18 & 28 & Peşinden koşmamak, konuşmamak \\
\hline İlişkiyi sonlandırma & 16 & 25 & Ayrılmak, sosyal medyadan engellemek \\
\hline $\begin{array}{l}\text { Şiddetin yoğunluğuna } \\
\text { bağlı olarak karar } \\
\text { verme }\end{array}$ & 14 & 22 & $\begin{array}{l}\text { Duygusal şiddetse ilişkiyi sonlandırmama, şiddetin üzerimde bıraktığı etkiye göre hareket } \\
\text { ederim }\end{array}$ \\
\hline $\begin{array}{l}\text { Sorunu çözmek için } \\
\text { eyleme geçme }\end{array}$ & 7 & 11 & İlişki için çabalama, problemi anlatma en son sonlandırma, konuşup düzeltme \\
\hline Aynısını faile yapma & 6 & 9 & Şiddet görürsem ben de vururum, aynı şekilde karşılık vermek için doğru zamanı beklerim \\
\hline Şikâyet etme & 2 & 3 & Polise bildirme \\
\hline Duygusal tepki verme & 1 & 2 & A ğlama \\
\hline Toplam & 64 & 100 & \\
\hline
\end{tabular}


Tablo 4. Şiddetin Gerekçeleri

\begin{tabular}{|c|c|c|c|}
\hline Kategoriler & $f$ & $\%$ & Katılımcıların söylemleri \\
\hline Bireysel & 47 & 42 & $\begin{array}{l}\text { Beklentilerin karşılanmaması, sadistik düşünceler, haz alma, iletişim eksikliği, } \\
\text { kıskançlık, fazla sahiplenme }\end{array}$ \\
\hline Ailesel & 3 & 2 & Aile içi şiddet yaşama, kız ve oğlan çocuklarının farklı yetiştirilmesi \\
\hline Bağlamsal & 56 & 50 & $\begin{array}{l}\text { Kadın erkek eşitsizliği, ataerkil düzen, adalet sistemindeki sorunlar, etnik yapı, } \\
\text { kültür, atasözleri, medyadaki ürünlerin şiddeti desteklemesi }\end{array}$ \\
\hline Şiddet döngüsü & 4 & 4 & Kendisi de şiddete maruz kalmış olabilir, daha önceki yaşantılarından dolayı \\
\hline $\begin{array}{l}\text { Daha büyük sorunları } \\
\text { önlemek }\end{array}$ & 3 & 2 & Şiddeti sorunları önleme yöntemi olarak görme \\
\hline Toplam & 113 & 100 & \\
\hline
\end{tabular}

bilgiler Tablo 3'te sunulmuştur.

Araştırmanın yedinci sorusu "Flört şiddeti uygulayan kişiler bunu neden yaparlar? Şiddetin gerekçeleri nelerdir?" katılımcıların şiddetin nedenleri konusunda cevap üretmelerini sağlamıştır. Şiddetin nedenleri, bireysel, ailesel, bağlamsal, şiddet döngüsü ve daha büyük sorunları önlemek olmak üzere 5 kategoride incelenmiştir. Katılımcıların yanıtlarının \%42'si $(f=47)$ bireysel, $\% 2$ 'si $(f=3)$ ailesel, \%50'si $(f=56)$ bağlamsal \%4'ü $(f=$ 4) şiddet döngüsü ve $\% 2$ 'si $(f=3)$ daha büyük sorunları önlemek hakkındadır. Katılımcıların bazıları da $(f=5)$ şiddetin nedeninin olmadığını belirtmiştir. Analize ilişkin bilgiler ve kategoriler Tablo 4'te sunulmuştur.

Çalışmanın sekizinci sorusu olan, "İlişskinizde sizi rahatsız eden durumları kimlere anlattınız? Ne gibi tepkiler aldınız?" 8 kategoride değerlendirilmiştir. Bunlar; arkadaşlara, aileye, flörte, bir uzmana, herkese, tarafsız birine anlatılabileceğini belirtenler; hiç kimseye ve aileme anlatmam diyenler şeklindedir. Katılımcıların \%38'i

Tablo 5. Flört Şiddeti Yaşantısının Paylaşıldığı Kişiler $(f=35)$ arkadaşlar, $\% 32$ 'si aile $(f=29), \% 8$ 'i $(f=6)$ flört, $\%$ 'ü $(f=4)$ bir uzman, \%1'i $(f=1)$ herkes ve $\% 1$ 'i $(f=$ 1) tarafsız kişilerle flört şiddeti yaşantılarını paylaşacaklarını belirtmişlerdir. Katılımcıların \%12'si $(f=11)$ hiç kimseye ve $\% 5$ 'i $(f=5)$ ailesine flört şiddeti yaşantılarını anlatmayacaklarını belirtmişlerdir. Analize ilişkin bilgiler ve kategoriler Tablo 5 'te sunulmuştur.

Araştırmanın dokuzuncu sorusunda ise flört şiddeti yaşantılarını paylaşmayanların nedenleri incelenmiştir. Flört şiddeti yaşantısını paylaşmayanların \%58'i $(f=15)$ olumsuz tepkilerden çekindiğini, \%30'u $(f=8)$ kendini suçladığını, \%8'i $(f=2)$ yakınlarının objektif olamayacağını düşündüğünü ve $\%$ '’ü $(f=1)$ çevresinde kimsenin olmadığını belirtmiştir.

Araştırmada son olarak "Flört şiddetinin azaltılmas1, önlenmesi için neler önerirsiniz?" sorusu sorularak katılımcıların flört şiddetini önleme stratejileri değerlendirilmiştir. Katılımcıların cevapları bireysel, ailesel ve topluma yönelik olmak üzere üç kategoride incelen-

\begin{tabular}{lccl} 
& & & \\
\hline Kategoriler & $f$ & $\%$ & Katılımcıların söylemleri \\
\hline Arkadaşlar & 35 & 38 & En yakın arkadaşıma, karşı cinsten bir arkadaşa, sevgilimin arkadaşlarına \\
Aile & 29 & 32 & Anneme, ablama, kuzenime, abime, babama, kardeşime \\
Hiç kimse & 11 & 12 & Mahremiyet korunmalı, kendim çözmeye çalışırdım \\
Flört & 6 & 8 & Sevgilimle konuşur çözmeye çalışırım \\
Aileme anlatmam & 5 & 5 & Üzülürler, bana verecekleri tepkiden korkarım \\
Bir uzman & 4 & 3 & Psikoloğa giderim \\
Herkes & 1 & 1 & Çevremdeki herkese anlatırım \\
Tarafsız biri & 1 & 1 & Tarafsız olduğunu düşündüğüm birine anlatırım \\
Toplam & 92 & 100 & \\
\hline
\end{tabular}


Tablo 6. Flört Şiddetini Önleme Stratejileri

\begin{tabular}{|c|c|c|c|}
\hline Kategoriler & $f$ & $\%$ & Katılımcıların söylemleri \\
\hline Bireysel & 36 & 34 & $\begin{array}{l}\text { Etkili: Sınır koyma, empati yapmayı öğrenme, saygı duymayı öğrenme, hayır } \\
\text { deme, karşılıklı konuşma, } \\
\text { Etkisiz: İlişkiye başlamamak, aynısını karşı tarafa yaşatmak }\end{array}$ \\
\hline Ailesel & 8 & 8 & Etkili: Ebeveynlik eğitimleri verme \\
\hline Bağlamsal & 62 & 58 & $\begin{array}{l}\text { Etkili: Eylem yapma, cinsiyetçi dili değiştirme, okullarda eğitim verme } \\
\text { Etkisiz: İdam, hadım, failler toplumdan dışlanmalı }\end{array}$ \\
\hline Toplam & 106 & 100 & \\
\hline
\end{tabular}

miştir. Kategoriler kendi içinde etkili ve etkisiz olarak sınıflandırılmıştır. Katılımcılardan bazıları $(f=3)$ flört şiddetinin önlenemeyeceğini belirtmiştir. Katılımcıların cevaplarının \%34'ünde $(f=36)$ bireysel, $\% 8$ 'inde $(f=$ 8) ailesel, $\% 58$ 'inde $(f=62)$ bağlamsal önleme stratejileri önerilmiştir. Kategoriler ve analiz sonuçlarına dair bilgiler Tablo 6'da sunulmuştur. Bireysel müdahalelerin $\% 69$ 'u $(f=25)$ etkili $\% 31$ 'i $(f=11)$ etkisiz olarak, ailesel müdahalelerin tamamı etkili olarak, bağlamsal müdahalelerin \%85'i $(f=53)$ etkili, \%15'i $(f=9)$ etkisiz olarak sınıflandırılmıştır.

\section{Tartışma}

$\mathrm{Bu}$ araştırmanın amacı, üniversite öğrencilerinin flört şiddetine yönelik algılarını, tutumlarını ve deneyimlerini derinlemesine incelemektir. Araştırmanın ilk sorusu, üniversite öğrencilerinin flört şiddetini nasıl tanımladıklarıdır. Katılımcılar flört şiddetini tanımlamaktan ziyade, kıskanma, bağırma gibi flört şiddeti davranışlarına örnekler vermişlerdir. Flört şiddetinin tanımının alanyazında bile net olmaması ve araştırmacılar arasında bir uzlaşma bulunmaması (Lewis ve Fremouw, 2001; Siewert ve Flanagan, 2000) dikkate alındığında katılımcılar tarafından tanımının yapılamaması oldukça doğal bir durumdur.

$\mathrm{Bu}$ araştırmanın ikinci ve üçüncü sorusu üniversite öğrencilerinin tanık oldukları ya da deneyimledikleri flört şiddeti türleri ile ilgilidir. Katılımcıların ifadelerinden yola çıkarak elde edilen frekanslarda katılımcıların en fazla duygusal şiddet türlerine örnekler verdiği görülmektedir. Duygusal şiddeti, cinsel ve fiziksel şiddet izlerken, en son sirada takip ve ekonomik şiddet gelmektedir. Bu çalışmada beklenenden daha az sayıda cinsel ve fiziksel şiddet içeren örnekler verilmiştir. Bu, en sıklıkla duygusal flört şiddetinin yaşandığını göstermektedir. Duygusal flört şiddeti tek başına görülebildiği gibi diğer şiddet türleri ile birlikte de görülebilir (Sharpe ve Taylor, 1999). Alanyazında da duygusal flört şiddetinin daha yaygın olduğu görülmektedir (Toplu ve Hatipoğlu-Sümer, 2011). Ancak bu bulgunun birtakım olası başka açıklamaları da olabilir. İlk olarak ülkemizin sosyokültürel yapısı düşünüldüğünde, cinselliğin hala bir tabu olması üniversite öğrencilerinin cinsel şiddet hakkında konuşmasını engellemiş olabilir. Ayrıca üniversite öğrencilerinin grup içinde fiziksel şiddet hakkında konuşmaktan çekinmiş olabilecekleri düşünülmüştür. Bu çalışma kapsamında gruplar oluşturulurken her ne kadar birbirini tanımayan, farklı bölümlerden öğrenciler bir araya getirilerek gruplar oluşturulsa da katılımcılar fiziksel şiddet hakkında konuşmaktan çekinmiş olabilirler. Bu çalışmadaki katılımcıların en son sırada takip ve ekonomik şiddetten bahsettikleri bulunmuştur. Bu bulgu alanyazını ile tutarlıdır. Yürütülen çalışmalarda da diğer şiddet türleri ile kıyaslandığında takip ve ekonomik şiddetin daha az rapor edildiği görülmektedir (Niolon vd., 2015; Sünetçi vd., 2016). Takip ve ekonomik şiddetin yaygınlığının diğer şiddet türlerine göre daha az olması katılımcıların bu şiddet türlerini tanımamasına neden olmuş olabilir.

Şiddet türleri için verilen örnekler incelendiğinde ise öğrencilerin sıklıkla zorlama/hakimiyet kurma, özel hayatı kısıtlama, hakaret etme, aşağılama ve kıskançlık temalarına dair söylemlerde bulundukları saptanmıştır. $\mathrm{Bu}$ bulgu alanyazını ile tutarlıdır (Dietrich, 1998; Fidan ve Yeşil, 2018). Fidan ve Yeşil (2018) tarafından üniversite öğrencileri ile yürütülen çalışmada da katılımcıların sosyal ve duygusal şiddete hayatı kısıtlama, bask1 yapma, giyimine karışma, küfür etme gibi örnekler verdikleri saptanmıştır. Cinsel şiddet temaları incelendiğinde ise katılımcılar en fazla fiziksel temas içeren cinsel şiddete örnek vermiştir. Ardından sırasıyla fiziksel temas içermeyen cinsel şiddet ve cinsel şiddete ortam hazırlamak gelmektedir. Alanyazında da cinsel şiddet genellikle fiziksel temas içeren ve içermeyen şeklinde ele alınırken 
(Polat, 2015), son y1llarda araştırmacılar cinsel şiddete ortam hazırlamak (grooming) kavramını da çalışmaktadır (Whittle vd., 2013). Ülkemizde de bu davranışların şiddet olarak algılanmaya başlanması ve farkındalık kazanılması şiddetin önlenmesi açısından önemlidir.

Bu çalışmanın dördüncü sorusu kapsamında katılımcılardan flört şiddeti uygulayan kişileri tanımlamaları istendiğinde, faillerin bireysel, ailesel ve bağlamsal özelliklerine vurgu yaptıkları görülmüştür. Şiddetin tek bir nedeni olmadığı, bireysel, ailesel ve bağlamsal çoklu risk faktörlerinin bir araya gelerek oluştuğu alanyazında belirtilmektedir (Cicchetti ve Lynch, 1993). Alanyazında flört şiddeti uygulayan erkeklerle yapılan bir çalışmada ise, şiddetin nedenlerinin daha çok ailesel (sağlıksız aile ortamı) ve bağlamsal özellikler (arkadaş ortamı, okulda akademik konularda destek olmaması, toplum şiddeti) olduğu vurgulanmıştır (Reed vd., 2008).

$\mathrm{Bu}$ çalışmanın beşinci sorusunda flört şiddetine maruz kalan kişilerin özellikleri tanımlanırken de bireysel, ailesel ve bağlamsal olmak üzere 3 kategorinin ortaya çıktığı görülmüştür. Alanyazında bu çalışmadaki temalara benzer biçimde flört şiddetine maruz kalmanın bireysel, ailesel ve bağlamsal birçok risk faktörü olduğ bilinmektedir (Brooks-Russell vd., 2013; Foshee vd., 2004). Ancak bu çalışmada bireysel ifadeler arasında dikkat çeken söylemlerden bazıları katılımcıların şiddeti meşrulaştırmaya ve normalleştirmeye yönelik olan ifadeleridir. Örneğin katılımcılar maruz kalanı tanımlarken "hak etmiştir, partnerini kışkırtmıştır ya da psikolojik sorunları bulunmaktadır” gibi söylemlerde bulunmuşlardır. Türkiye gibi şiddetin yaygın olduğu ülkelerde faili değil, maruz kalanı suçlamanın yaygın olduğu belirtilmektedir (Parlan, 2015). Alanyazındaki niteliksel çalışmalarda da maruz kalanı suçlama ve şiddeti meşrulaştırmaya yönelik temalar olduğu görülmektedir (Black ve Weisz, 2005; Johnson vd., 2005). Ülkemizde, Fidan ve Yeşil (2018) tarafından yapılan niteliksel çalışmada da flört şiddetine maruz kalan öğrenciler, failin davranışlarının nedeni olarak partnerlerinin karakterini, sosyal çevreyi ve kendi tutumlarını belirtmişlerdir.

$\mathrm{Bu}$ çalışmanın altıncı sorusu kapsamında katılımcılara flört şiddetine maruz kaldıklarında ya da kalırlarsa ne yapacakları sorulduğunda katılımcıların en sık olarak bir şey yapmama, ilişkiyi sonlandırma ve şiddetin yoğunluğuna bağlı olarak karar verme davranışlarını belirttikleri görülmüştür. Katılımcıların genellikle aktif olarak harekete geçmek için gönüllü olmadıkları, "durumu akışına bıraktıkları”" görülmüştür. Fidan ve Yeşil (2018) tarafından yapılan çalışmada da kadınların 1/6'sının, erkeklerin ise $1 / 3$ 'ünün deneyimlenen flört şiddeti sonras1 ilişkiyi sonlandırdıkları belirtilmektedir. Diğer katılımc1lar bu çalışmadaki söylemlere benzer bir biçimde flört şiddeti sonrası ilişkilerini sonlandırmadıklarını ve her- hangi bir aktif eylemde bulunmadıklarını bildirmişlerdir. Katılımcıların herhangi bir şey yapmama ya da ilişkiyi sonlandırmama nedenleri çok sevmeleri, bir kerelik olduğuna inanmaları, ayrılmak istememeleri, faile ya da kendilerine yapılan atıflar olabilir (Fidan ve Yeşil, 2018; Öztürk vd., 2018). Dolayısıyla flört şiddetini önlemek için gençlerin flört şiddetinin özellikleri (tekrarlanması ve giderek şiddetin artması gibi) konusunda bilgilendirilmeye ihtiyaç duydukları görülmektedir.

Araştırmanın yedinci sorusunda flört şiddetinin gerekçeleri sorulduğunda katılımcıların cevapları, bireysel, ailesel, bağlamsal, şiddet döngüsü ve daha büyük sorunları önlemek olmak üzere 5 kategoride toplanmıştır. Alanyazında da bu bulgu ile tutarlı bir biçimde şiddet ile ilişkili olan çoklu risk faktörlerinden ve bu faktörlerin birbiri ile karşıllklı etkileşiminden bahsedilmektedir (Banyard, 2011; Salzinger vd., 2002). Vagi ve arkadaşları (2013) tarafindan yapılan derleme çalışmasında 2000 ve 2010 yılları arasında yayınlanmış 20 çalışma incelenmiş ve flört şiddetindeki failin risk ve koruyucu faktörleri değerlendirilmiştir. Bu risk ve koruyucu faktörler Bronfenbrenner'in (1979) Sosyo-Ekolojik Kuramına dayanarak sınıflandırılmış ve 53 risk faktörü ve 6 koruyucu faktör olduğu belirtilmiştir. Bireysel risk faktörlerine ilişkide şiddeti normal kabul etme, saldırganlık, alkol kullanımı ve stres; ilișki temelli risk faktörlerine çocukluk döneminde istismara maruz kalma, aile içi şiddete tanık olma, akran zorbalığ lerin yetersiz ebeveynlik becerilerine sahip olması örnek olarak verilebilir. Bireysel koruyucu faktörler yüksek empati, ortalama akademik başarı ve sözel zekâ iken, ilişki temelli koruyucu faktörlerin anneyle olumlu ilişki ve okula bağlanma olduğu belirtilmiştir. Bu çalışmadaki katılımcıların belirttiği risk faktörlerine benzer şekilde Vagi ve arkadaşlarının (2013) çalışmasında da çoklu risk faktörlerine vurgu yapılmıştır.

Çalışmanın sekizinci sorusunda katılımcılar ilişkilerinde onları rahatsız eden şeyleri en s1k olarak arkadaş ve ailelerinden birine anlatacaklarını belirtmişlerdir. Martin ve arkadaşları (2012) tarafindan yürütülen çalışmada da flört şiddetine maruz kalanların profesyonellerden ziyade akran ve aileler gibi resmi olmayan kaynaklardan yardım istedikleri bulunmuştur. Benzer şekilde Latin ergenlerle yapılan çalışmada, katılımcılar flört şiddeti yaşantılarını resmî kurumlara bildirmek yerine aile ve arkadaşlarıyla daha fazla paylaşma eğilimindedir (Ocampo vd., 2007). Oysa flört şiddeti toplumda yeni tanınmaya başlayan bir olgu olduğundan çoğu arkadaş ve aile üyesinin bu durumda sağlıklı bir yaklaşım sergileyememesi mümkündür. Hatta yanlış biçimde şiddete maruz kalıp açılan kişiye sorumluluk yüklenmesi de söz konusu olabilir. Bu çalışmada da bazı katılımcıların şiddete maruz kalan kişiyi tanımlarken "hak etmiştir veya partneri- 
ni kışkırtmıştır" gibi suçlayıcı ifadeler kullandıkları da daha önce belirtilmişti. Bu yoruma paralel biçimde bu sorudaki ifadelerden bazılarında flört şiddeti yaşantısını hiç kimseye anlatmayacakları belirtilmiştir. Ashley ve Foshee (2005) tarafından yürütülen çalışmada kadın ve erkek katılımcıların çoğunluğunun flört şiddeti sonras1 yardım arama davranışında bulunmak istemedikleri bulgulanmıştır. Bu sorunun devamı olarak bu araştırmanın dokuzuncu sorusunda flört şiddeti yaşantılarını paylaşmama nedenleri incelenmiştir. Katılımcıların söylemlerinden yola çıkarak oluşan temalar sırasıyla olumsuz tepkilerden çekinme, kendini suçlama, yakınlarındaki kişilerin objektif olmayacaklarını belirtme ve çevresinde kimsenin olmaması şeklindedir. Bu çalışmanın bulgularına benzer olarak alanyazında da ergenler ve üniversite öğrencileri flört şiddeti sonrası yardım arama davranışlarında utanç duyma, yardım kaynakları hakkında bilginin az olması, etiketlenme korkusu, gizlilikle ilgili endişeler gibi birçok engel ile karşılaşmaktadır (Ashley ve Foshee, 2005; Martin vd., 2012). Dolayısıyla flört şiddeti konusunda uzmanlardan yardım aramanın teşvik edilmesi maruz kalanların ihtiyaç duydukları bilgilendirme ve desteğe ulaşabilmesi bakımından yararlı olacaktır. $\mathrm{Bu}$ ihtiyaca karşılık verilebilmesi için uzmanların bilgilendirilmesi de önem taşımaktadır.

Araştırmanın son sorusu flört şiddetinin azaltılması ve önlenmesi üzerinedir. Katılımcıların verdikleri yanıtlar bireysel, ailesel ve topluma yönelik olmak üzere üç kategoriye ayrılmıştır. Bu cevaplar araştırmacılar tarafından etkili ve etkisiz olarak da sınıflandırılmıştır. Katılımcılar flört şiddetini önlemek için ilk sırada topluma yönelik çalışmalara ihtiyaç olduğunu belirtmişlerdir. $\mathrm{Bu}$ cevapların çoğunluğu etkilidir. Alan yazınında da toplumsal düzeyde farkındalık yaratan ve flört şiddetini önlemeyi amaçlayan birçok çalışma bulunmaktadır (Cornelius ve Resseguie, 2007; Herman, 2009; Üstünel, 2020). Ayrıca bu çalışmanın da bir dayanağı olan Ekolojik Kuramlara göre, şiddeti önlemek bireysel bir çabadan ziyade toplumsal bir eylem gerektirmektedir (Casey ve Lindhorst, 2009; Cicchetti ve Lynch, 1993). Ancak toplumsal düzeyde verilen cevapların bir kısmı idam etme, hadımı içeren kanun değişiklikleri ve toplum tarafından dışlanma gibi etkisiz müdahaleleri içermektedir. Bu cevapların verilmesinin olası nedenleri şunlar olabilir: İlk olarak, ülkemiz bağlamında düşünüldüğünde, şiddet ve istismar gibi medyaya yansıyan haberlerde hem yayın organları hem siyasetçiler sürekli olarak idam ve hadım seçeneklerini gündeme getirmektedir. Bu tanıklıklara ek olarak katılımcıların faillere yönelik öfke, intikam alma gibi duyguları nedeniyle de bu söylemler ortaya çıkmış olabilir.

$\mathrm{Bu}$ çalışma, üniversite öğrencilerinin flört şiddeti tanımlarını, flört şiddeti çeşitlerini, öğrencilerin flört şid- deti deneyimlerini, şiddetin nedenlerini, flört şiddeti ile baş etme yöntemlerini ve flört şiddetini önleme yöntemlerini ilk kez bir arada ve kapsamlı olarak ele almaktadır. Çalışmada dört erkek grubu, dört kadın grubu olmak üzere 78 katılımcı ile sekiz odak grup görüşmesi yürütülmesi örneklemin heterojenliğini güçlendirmektedir. Ayrıca odak grup görüşmelerinin sayısı araştırmanın geçerliği ve güvenirliğine katkı sağlamaktadır. Odak grup görüşmelerinin yürütülmesinin de katılımcılar için dinamik ve etkileşimli bir ortam sunması bakımından araştırmanın güçlü bir yönü olduğu düşünülmektedir. Odak grup görüşmelerinde katılımcılarla aynı cinsiyette görüşmecilerin olmasına dikkat edilmesinin katılımcıların kendini açmalarını ve güvenilir bilgiler vermelerini etkilemiş olabileceği düşünülmektedir.

$\mathrm{Bu}$ çalışmanın birtakım sınırlılıkları bulunmaktadır. İlk olarak, bu çalışmanın güçlü yanlarından biri olan odak grup görüşmesi yürütülmesi aynı zamanda bu çalışmanın bir sınırlılığıdır. Her ne kadar öğrencilerin birbirini tanımadığ gruplar oluşturulmaya dikkat edilse de bazı öğrenciler grup sürecinden etkilenmiş ve doğru bilgiler vermemiş olabilirler. İkinci olarak, bu çalışmanın bulguları üniversite öğrencilerinin deneyimlerine dayanmaktadır. Farklı yaş gruplarındaki bir çalışma grubu ile araştırmanın tekrarlanması önerilmektedir. Ayrıca bu çalışmada üniversite öğrencilerinin daha önceden flört şiddetine maruz kalıp kalmaması ya da flört şiddeti uygulayıp uygulamamasına dikkat edilmemiştir. Diğer çalışmalar flört şiddetine maruz kalanlardan ya da faillerden oluşan üniversite öğrencileri ile yürütülebilir.

Flört şiddeti, bireyler üzerinde olumsuz etkileri olan yaygin bir problemdir. $\mathrm{Bu}$ nedenle bu problemin akademisyenler, uzmanlar, öğretmenler, politika yap1cılar tarafından tanınması oldukça önlemlidir. Ayrıca bu konuda ülkemizde geliştirilecek daha fazla sayıda önleme ve müdahale çalışmasına ihtiyaç bulunmaktadır. 


\section{Kaynaklar}

Ackard, D. M., Eisenberg, M. E. ve Neumark-Sztainer, D. (2007). Long-term impact of adolescent dating violence on the behavioral and psychological health of male and female youth. The Journal of Pediatrics, 151(5), 476-481. https://doi.org/10.1016/j. jpeds.2007.04.034.

Ackard, D. M. ve Neumark-Sztainer, D. (2002). Date violence and date rape among adolescents: Associations with disordered eating behaviors and psychological health. Child Abuse \& Neglect, 26(5), 455-473. https://doi.org/10.1016/S01452134(02)00322-8.

Amar, A. F. ve Gennaro, S. (2005). Dating violence in college women: Associated physical injury, healthcare usage, and mental health symptoms. Nursing Research, 54(4), 235-242.

Ashley, O. S. ve Foshee, V. A. (2005). Adolescent help-seeking for dating violence: Prevalence, sociodemographic correlates, and sources of help. Journal of Adolescent Health, 36(1), 25-31. https:// doi.org/10.1016/j.jadohealth.2003.12.014.

Baker, C. K., Helm, S., Bifulco, K. ve Chung-Do, J. (2015). The relationship between self-harm and teen dating violence among youth in Hawaii. Qualitative Health Research, 25(5), 652-667. https:// doi.org/10.1177/1049732314553441.

Baltac1, A. (2019). Nitel araştırma süreci: Nitel bir araştırma nasıl yapılır?. Ahi Evran Üniversitesi Sosyal Bilimler Enstitüsü Dergisi, 5(2), 368-388. https://doi.org/10.31592/aeusbed.598299.

Banyard, V. L. (2011). Who will help prevent sexual violence: Creating an ecological model of bystander intervention. Psychology of Violence, 1(3), 216229. https://doi.org/10.1037/a0023739.

Bilgin, N. (2000). İçerik analizi. Ege Üniversitesi Edebiyat Fakültesi.

Black, B. M. ve Weisz, A. N. (2005). Dating violence: A qualitative analysis of Mexican American youths' views. Journal of Ethnic and Cultural Diversity in Social Work, 13(3), 69-90. https://doi.org/10.1300/ J051v13n03 04.

Bronfenbrenner, U. (1979). The ecology of human development. Harvard University Press.

Brooks-Russell, A., Foshee, V. A. ve Ennett, S. T. (2013). Predictors of latent trajectory classes of physical dating violence victimization. Journal of Youth and Adolescence, 42(4), 566-580. doi: https://doi. org/10.1007/s10964-012-9876-210.1007/s10964012-9876-2.

Callahan, M. R., Tolman, R. M. ve Saunders, D. G. (2003). Adolescent dating violence victimization and psychological well-being. Journal of $\mathrm{Ad}$ olescent Research, 18(6), 664-681. https://doi. org/10.1177/0743558403254784.

Casey, E. A. ve Lindhorst, T. P. (2009). Toward a multi-level, ecological approach to the primary prevention of sexual assault: Prevention in peer and community contexts. Trauma, Violence, \& Abuse, 10(2), 91114. https://doi.org/10.1177/1524838009334129

Centers for Disease Control and Prevention (CDC) (2016). Teen Dating Violence Fact Sheet https:// www.cdc.gov/violenceprevention/pdf/teen-dating-violence-factsheet-a.pdf adresinden edinilmiştir.

Choi, H. J. ve Temple, J. R. (2016). Do gender and exposure to interparental violence moderate the stability of teen dating violence?: Latent transition analysis. Prevention Science, 17(3), 367-376. https://doi. org/10.1007/s11121-015-0621-4

Ciairano, S., Bonino, S., Kliewer, W., Miceli, R. ve Jackson, S. (2006). Dating, sexual activity, and well-being in Italian adolescents. Journal of Clinical Child \& Adolescent Psychology, 35(2), 275-282, https:// doi.org/10.1207/s15374424jccp3502_11.

Cicchetti, D. ve Lynch, M. (1993). Toward an ecologi$\mathrm{cal} /$ transactional model of community violence and child maltreatment: Consequences for children's development. Psychiatry, 56, 96-118. https://doi.or $\mathrm{g} / 10.1080 / 00332747.1993 .11024624$.

Cornelius, T. L. ve Resseguie, N. (2007). Primary and secondary prevention programs for dating violence: A review of the literature. Aggression and Violent Behavior, 12(3), 364-375. https://doi. org/10.1016/j.avb.2006.09.006.

Cüceloğlu D. (1991). Insan ve davranışı. Remzi Kitabevi.

Çimen, O. (2018). Heteroseksüel gençlerin flört şiddetine yönelik söylemleri (Yayınlanmamış yüksek lisans tezi). İstanbul Arel Üniversitesi, Sosyal Bilimler Enstitüsü

Debowska, A., Boduszek, D. ve Willmott, D. (2018). Psychosocial correlates of attitudes toward male sexual violence in a sample of financial crime, property crime, general violent, and homicide offenders. Sexual Abuse, 30(6), 705-727. https://doi. org/10.1177/1079063217691966.

Dietrich, L. C. (1998). Chicana adolescents: Bitches, 'ho's, and schoolgirls. Greenwood Publishing Group

Dikmen H.A., Özaydın T. ve Y1lmaz S. D. (2018). Üniversitedeki kadın öğrencilerde yaşanan flört şiddeti ile anksiyete ve umutsuzluk düzeyleri arasındaki ilişki. Acıbadem Üniversitesi Sağlık Bilimleri Dergisi, 9, 170-176. https://doi.org/10.31067/0.2018.9. 
Earnest A. A. ve Brady S. S. (2016). Dating violence victimization among high school students in Minnesota: Associations with family violence, unsafe schools, and resources for support. Journal of Interpersonel Violence, 31, 383-406. https://doi. org/10.1177/0886260514555863.

Ely, G. E. (2004). Dating violence. Lisa A. Rapp-Paglicci, Catherine N. Dulmus ve John S. Wodarski (Ed.), Handbook of preventive interventions for children and adolescents içinde. (ss. 415 - 437). Wiley.

Erikson, E. (1959). Childhood and society. Norton.

Fidan, F. ve Yeşil, Y. (2018). Nedenleri ve sonuçları itibariyle flört şiddeti. Balkan ve Yakın Doğu Sosyal Bilimler Dergisi, 4, 16-24.

Follette, V. M. ve Alexander, P. C. (1992). Dating violence: Current and historical correlates. Behavioral Assessment, 14(1), 39-52.

Follingstad, D. R., Wright, S., Lloyd, S. ve Sebastian, J. A. (1991). Sex differences in motivations and effects in dating violence. Family Relations, 40, 5157. https://doi.org/10.2307/585658.

Foshee, V. A., Benefield, T. S., Ennett, S. T., Bauman, K. E. ve Suchindran, C. (2004). Longitudinal predictors of serious physical and sexual dating violence victimization during adolescence. Preventive Medicine, 39(5), 1007-1016. https://doi.org/10.1016/j. ypmed.2004.04.014.

Fredland, N. M., Ricardo, I. B., Campbell, J. C., Sharps, P. W., Kub, J. K. ve Yonas, M. (2005). The meaning of dating violence in the lives of middle school adolescents: A report of a focus group study. Journal of School Violence, 4(2), 95-114. https://doi. org/10.1300/J202v04n02_06.

Frieze, I. H. (2000). Violence in close relationships - development of a research area: Comment on Archer (2000). Psychological Bulletin, 126(5), 681-684. https://doi.org/10.1037/0033-2909.126.5.681

Gander, M. ve Gardiner, H. (2010). Çocuk ve ergen gelişimi (çev. A. Dönmez). İmge Kitabevi.

Gressard, L. A., Swahn, M. H. ve Tharp, A. T. (2015). A first look at gender inequality as a societal risk factor for dating violence. American Journal of Preventive Medicine, 49(3), 448-457. https://doi. org/10.1016/j.amepre.2015.05.017.

Gwartney-Gibbs P. A., Stockard, J. ve Bohmer, S. (1987). Learning courtship aggression: The influence of parents, peers, and personal experiences. Family Relations, 36, 276-282. https://doi. org/10.2307/583540

Harned, M. S. (2002). A multivariate analysis of risk markers for dating violence victimization. Journal of Interpersonal Violence, 17(11), 1179-1197. https://doi.org/10.1177/088626002237401
Harris, J. R. (1995). Where is the child's environment? A group socialization theory of development. Psychological Review, 102(3), 458-489. https://doi. org/10.1037/0033-295X.102.3.458

Heise L. L. (1998). Violence against women: an integrated, ecological framework. Violence Against Women, 4, 262-290. https://doi.org/10.1177\% 2F1077801298004003002

Herman, J. W. (2009). There's a fine line...adolescent dating violence and prevention. Pediatric Nursing, 35(3), 164-170.

Johnson, S. B., Frattaroli, S., Campbell, J., Wright, J., Pearson-Fields, A. S. ve Cheng, T. L. (2005). "I know what love means." Gender-based violence in the lives of urban adolescents. Journal of Women's Health, 14(2), 172-179. https://doi.org/10.1089/ jwh.2005.14.172

Kaukinen, C. (2014). Dating violence among college students: The risk and protective factors. Trauma, Violence, \& Abuse, 15, 283-296. https://doi. org/10.1177\%2F1524838014521321

Kaukinen, C., Gover, A. R. ve Hartman, J. L. (2012). College women's experiences of dating violence in casual and exclusive relationships. American Journal of Criminal Justice, 37, 146-162. https://doi. org/10.1007/s12103-011-9113-7

Kayı, Z., Yavuz, M. F. ve Arıcan, N. (2000). Kadın üniversite gençliği ve mezunlarına yönelik cinsel saldırı mağdur araştırması. Adli Tıp Bülteni, 5(3), 157-163. https://doi.org/10.17986/blm.200053421

Krueger, R. ve Casey, M. (2015). Focus groups: A practical guide for applied research (5. bask1). Sage.

Laner, M. R. ve Thompson, J. (1982). Abuse and aggression in courting couples. Deviant Behavior, 3, 229-244. https://doi.org/10.1080/01639625.1982.9967588

Leisring, P. A. (2013). Physical and emotional abuse in romantic relationships: Motivation for perpetration among college women. Journal of Interpersonal Violence, 28, 1437-1454. https://doi. org/10.1177\%2F0886260512468236

Lewis, S. F. ve Fremouw, W. (2001). Dating violence: A critical review of the literature. Clinical Psychology Review, 21(1), 105-127. https://doi.org/10.1016/ S0272-7358(99)00042-2

Makepeace, J. M. (1981). Courtship violence among college students. Family Relations, 30, 97-102. https://doi.org/10.2307/584242

Martin, C. E., Houston, A. M., Mmari, K. N. ve Decker, M. R. (2012). Urban teens and young adults describe drama, disrespect, dating violence and help-seeking preferences. Maternal and Child Health Journal, 16(5), 957-966. https://doi. org/10.1007/s10995-011-0819-4 
McDonald, D. L. ve McKinney, J. P. (1994). Steady dating and self-esteem in high school students. Journal of Adolescence, 17(6), 557-564. https://doi. org/10.1006/jado.1994.1049

Mulawa, M., Kajula, L. J., Yamanis, T. J., Balvanz, P., Kilonzo, M. N. ve Maman, S. (2018). Perpetration and victimization of intimate partner violence among young men and women in Dar es Salaam, Tanzania. Journal of Interpersonel Violence, 33(16), 2486-2511. https://doi. org/10.1177\%2F0886260515625910

Niolon, P. H., Vivolo-Kantor, A. M., Latzman, N. E., Valle, L. A., Kuoh, H., Burton, T., ... ve Tharp, A. T. (2015). Prevalence of teen dating violence and co-occurring risk factors among middle school youth in high-risk urban communities. Journal of Adolescent Health, 56(2), 5-13. https://doi. org/10.1016/j.jadohealth.2014.07.019.

Noland, V. J., Liller, K. D., McDermott, R. J., Coulter, M. L. ve Seraphine, A. E. (2004). Is adolescent sibling violence a precursor to college dating violence?. American Journal of Health Behavior, 28, 13-23. https://doi.org/10.5993/AJHB.28.s1.3

Ocampo, B. W., Shelley, G. A. ve Jaycox, L. H. (2007). Latino teens talk about help seeking and help giving in relation to dating violence. Violence Against Women, 13(2), 172-189. https://doi. org/10.1177/1077801206296982

Offenhauer, P. ve Buchalter, A. (2011). Teen dating violence: A literature review and annotated bibliography. https://www.ncjrs.gov/pdffiles1/nij/ grants/235368.pdf adresinden edinilmiştir.

O'Keefe, M. (2005). Teen dating violence: A review of risk factors and prevention efforts. National Electronic Network on Violence Against Women, 1, $1-13$.

O'Keefe, M. ve Treister, L. (1998). Victims of dating violence among high school students: Are the predictors different for males and females?. Violence Against Women, 4, 195-223. https://doi.org/10.117 7\%2F1077801298004002005

Olshen, E., McVeigh, K. H., Wunsch-Hitzig, R. A. ve Rickert, V. I. (2007). Dating violence, sexual assault, and suicide attempts among urban teenagers. Archives of Pediatrics \& Adolescent Medicine, 161(6), 539-545. https://doi.org/10.1001/archpedi.161.6.539

Öztürk, N., Karabulut, M. ve Sertoğlu, E. (2018). Gençlerle güvenli ilişkiler üzerine çalışmak: Eğitimciler ve danışmanlar için el kitabı. (2. Bask1). Punto Bask1 Çözümleri

Page, A. Z. ve İnce, M. (2008). Aile içi şiddet konusunda bir derleme. Türk Psikoloji Yazıları, 11, 81-94.
Parker, E. M., Debnam, K., Pas, E. T. ve Bradshaw, C. P. (2016). Exploring the link between alcohol and marijuana use and teen dating violence victimization among high school students: The influence of school context. Health Education \& Behavior, 43(5), 528-536. https://doi. org/10.1177\%2F1090198115605308

Parlan, Y. (2015). Intimate partner violence-Who is to blame? (Yayınlanmamış Yüksek Lisans Tezi), Doğu Akdeniz Üniversitesi (DAÜ)

Polat, O. (2015). Şiddet. Seçkin Yayıncılık

Reed, E., Silverman, J. G., Raj, A., Rothman, E. F., Decker, M. R., Gottlieb, B. R., ... Miller, E. (2008). Social and environmental contexts of adolescent and young adult male perpetrators of intimate partner violence: A qualitative study. American Journal of Men's Health, 2(3), 260-271. https://doi. org/10.1177/1557988308318863

Reidy, D. E., Smith-Darden, J. P., Cortina, K. S., Kernsmith, R. M. ve Kernsmith, P. D. (2015). Masculine discrepancy stress, teen dating violence, and sexual violence perpetration among adolescent boys. Journal of Adolescent Health, 56, 619-624. https://doi.org/10.1016/j.jadohealth.2015.02.009

Riggs, D. S. ve O'Leary, K. D. (1989). A theoretical model of courtship aggression. M. A. Pirog-Good ve J. E. Stets (Ed.), Violence in dating relationships: Emerging social issues içinde (ss. 53-71). Praeger.

Rizzo, C. J., Joppa, M. C., Barker, D., Zlotnick, C., Warren, J., Saint-Eloi Cadely, H. ve Brown, L. K. (2020). Individual and relationship characteristics of adolescent girls with histories of physical dating violence. Journal of Interpersonal Violence, 35(5-6), 1389-1414. https://doi. org/10.1177\%2F0886260517696859

Rothman, E. F., McNaughton Reyes, L., Johnson, R. M. ve LaValley, M. (2012). Does the alcohol make them do it? Dating violence perpetration and drinking among youth. Epidemiologic Reviews, 34(1), 103-119. https://doi.org/10.1093/epirev/mxr027

Roscoe, B. ve Benaske, N. (1985). Courtship violence experienced by abused wives: Similarities in patterns of abuse. Family Relations, 34, 419-424. https://doi.org/10.2307/583582

Salzinger, S., Feldman, R. S., Stockhammer, T. ve Hood, J. (2002). An ecological framework for understanding risk for exposure to community violence and the effects of exposure on children and adolescents. Aggression and Violent Behavior, 7(5), 423-451. https://doi.org/10.1016/S1359-1789(01)00078-7

Samet, N. ve Kelly, E. W. (1987). The relationship of steady dating to self $\square$ esteem and sex role identity among adolescents. Adolescence, 22, 231-245. 
Sharpe, D. ve Taylor, J. K. (1999). An examination of variables from a social-developmental model to explain physical and psychological dating violence. Canadian Journal of Behavioural Science / Revue canadienne des sciences du comportement, 31(3), 165-175. https://doi.org/10.1037/h0087085

Siewert, P. A. ve Flanagan, A. Y. (2000). Filipino American dating violence: Definitions, contextual justifications, and experiences of dating violence. Journal of Human Behavior in the Social Environment, 3(3-4), 115-133. https://doi.org/10.1300/ J137v03n03 09

Smith, D. M. ve Donnelly, J. (2000). Adolescent dating violence: A multi-systemic approach of enhancing awareness in educators, parents, and society. Journal of Prevention \& Intervention in the Community, 21(1), 53-64. https://doi.org/10.1300/ J005v21n01_04

Stets, J. E. ve Pirog-Good, M. A. (1987). Violence in dating relationships. Social Psychology Quarterly, 50, 237-246. https://doi.org/10.2307/2786824

Sugarman, D. B. ve Hotaling, G. T. (1989). Dating violence: Prevalence, context, and risk markers. M. A. Pirog-Good ve J. E. Stets (Ed.), Violence in dating relationships: Emerging social issues içinde (ss. 3-32). Praeger.

Sünetçi, B., Say, A., Gümüştepe, B., Enginkaya, B., Yıldızdoğan, Ç. ve Yalçın, M. (2016). Üniversite öğrencilerinin flört şiddeti algıları üzerine bir araştırma. Ufkun Ötesi Bilim Dergisi, 16(1), 56-83.

Swahn, M. H., Bossarte, R. M. ve Sullivent, E. E. (2008). Age of alcohol use initiation, suicidal behavior, and peer and dating violence victimization and perpetration among high-risk, seventh-grade adolescents. Pediatrics, 121(2), 297-305. https:// doi.org/10.1542/peds.2006-2348

Temple, J. R., Choi, H. J., Reuter, T., Wolfe, D., Taylor, C. A., Madigan, S. ve Scott, L. E. (2018). Childhood corporal punishment and future perpetration of physical dating violence. The Journal of Pediatrics, 194, 233-237. https://doi.org/10.1016/j. jpeds.2017.10.028

Toplu, E. ve Hatipoglu-Sümer, Z. (2011, Ekim). Flört ilişkisinde şiddetin yaygınlığ 1 ve türleri. XI. Ulusal Psikolojik Danışma ve Rehberlik Kongresi, Selçuk, İzmir.

Üstünel. A. Ö. (2020). A feminist approach to dating violence prevention: Creating change towards safety, equality and mutuality. Feminism \& Psychology, 30, 143-164. https://doi. org/10.1177/0959353519882462

Vagi, K. J., Rothman, E. F., Latzman, N. E., Tharp, A. T., Hall, D. M. ve Breiding, M. J. (2013). Beyond cor- relates: A review of risk and protective factors for adolescent dating violence perpetration. Journal of Youth and Adolescence, 42(4), 633-649. https://doi. org/10.1007/s10964-013-9907-7

Van Ouytsel J., Ponnet K., Walrave M. ve d'Haenens L. (2017). Adolescent sexting from a social learning perspective. Telematics and Informatics, 34, 287298. https://doi.org/10.1016/j.tele.2016.05.009

White, J. W. ve Kowalski, R. M. (1998). Male violence toward women: An integrated perspective. R. G. Geen \& E. Donnerstein (Ed.), Human aggression: Theories, research, and implications for social policy içinde (ss. 203-228). Academic Press. https:// doi.org/10.1016/B978-012278805-5/50009-2

Whittle, H. C., Hamilton-Giachritsis, C. ve Beech, A. R. (2013). Victims' voices: The impact of online grooming and sexual abuse. Universal Journal of Psychology, 1(2), 59-71. https://doi.org/10.13189/ ujp.2013.010206

World Health Organization (2002). The World Health Report 2002: Reducing risks, promoting healthy life. Geneva, World Health Organization.

World Health Organization. (2005). WHO multi-country study on women's health and domestic violence against women initial results on prevalence, health outcomes and women's responses. Geneva: WHO Press, World Health Organization.

Yıldırım, A. ve Şimşek H. (2013). Sosyal bilimlerde nitel araştırma yöntemleri. Seçkin Yayıncılı. 


\section{Summary \\ Understanding Dating Violence: A Qualitative Study}

\author{
Duygu Eslek ${ }^{1}$ \\ Ege University
}

\author{
Rukiye Kizlltepe \\ Ege University
}

\author{
Türkan Y1lmaz Irmak \\ Ege University
}

Dating violence refers to engaging in physical, verbal, sexual, psychological, and economic violence in a romantic relationship or imposing social restrictions on the partner(s) (Polat, 2015). Dating violence is investigated within its five aspects: physical, emotional, sexual, economic, and stalking. Research on violence points out that violence in dating relationships is at least as typical as in marriage (Makepeace, 1981; Roscoe \& Bemaske, 1985). In a study with a sample of college students, Sugarman and Hotaling (1989) found that the rate of violence in dating relationships was approximately 30\%, similar to in marriage. Dating violence is a common public health problem. Risk factors of dating violence are scrutinized to explore dating violence more effectively.

The Ecological/Transactional Model developed by Cicchetti and Lynch (1993) emphasizes individual, familial, and contextual factors to explain violent behaviors; therefore, this study employed these categories to examine risk factors of dating violence. Considering personal characteristics, those who have low relationship satisfaction, change partners excessively, have low self-esteem (Ackard \& Neurmark-Sztainer, 2002; O'Keefe \& Treister, 1988), experience anger and depression (O'Keefe, 2005), use alcohol and substances (Harned, 2002), and take sexual risks (Kaukinen, 2014) are reported to exert dating violence more. In the context of familial characteristics, those who have been subjected to domestic violence (O'Keefe, 2005), punished by their parents in childhood (Temple et al., 2018), neglected (Earnest \& Brady, 2016), exposed to sexual abuse (Debowska et al., 2017) are reported to be inclined to dating violence more. Finally, cultural structure and the meanings attributed to gender roles have often been examined as contextual factors of dating violence (Reidy et al., 2015). In Turkey, Page and Ince (2008) suggested that the desire of men to control and punish women and to exercise and demonstrate power on them prevails when it comes to violence against women. Patriarchal family structure, isolation of women from the social environment, and discrepancies between educational attainments of couples are known to increase the risk of violence (Heise, 1998). Dating violence, which encompasses a large part of society and poses several risk factors, has many adverse consequences.

Individuals subjected to dating violence were previously found to report low self-esteem, self-blame, anger, anxiety (Makepeace, 1986; Smith \& Donnel1y, 2001), depression (Callahan et al., 2003), smoking and substance use (Ackard et al., 2007), eating disorders (Ackard \& Neumark-Sztainer, 2002), and suicidal thoughts and attempts (Ackard et al., 2007). There are also findings that dating violence may be a precursor to domestic violence in the future (Frieze, 2000; Smith \& Donnelly, 2001), which reinforces the cycle of violence.

As evident in the literature, dating violence has many short- or long-term adverse effects on university students. For this reason, conducting a qualitative study appeared as a must to obtain an in-depth understanding of dating violence. Ultimately, this study aimed to explore male and female university students' thoughts and experiences about dating violence.

\section{Method}

\section{Participants}

The sample of the study was composed of 78 university students enrolled at Ege University. While 56\% $(n=44)$ of the participants were females, $44 \%(n=34)$ were males. The age range of the students was 18-22 years $(M=19, S D=1.2)$.

\section{Data Collection Instruments}

The researchers generated open-ended questions to investigate the perceptions, experiences, and attitudes of the participants concerning dating violence. Some questions used in the focus group interviews are: "What is dating violence?" "Could you tell us about the behaviors exhibited by the person you like and making you feel scared?" "Could you tell us about your behaviors making the person you like feel uncomfortable and frightened?" "How would you describe the people who have committed dating violence in your relationship or other

Address for Correspondence: ${ }^{1}$ Res. Asst. Duygu Eslek, Ege University, Faculty of Literature, Department of Psychology, 35100 Bornova / Izmir.

E-mail: duygu.eslek@gmail.com 
relationships you know about?", "What would you say about the people who have experienced dating violence in your relationship or other relationships you know about?"

\section{Procedure and Data Analysis}

Ege University Scientific Research and Publication Ethics Committee granted the ethical permission for the research. We also sought relevant permissions from the lecturers of the classes where we conducted the present study. Then, female and male interviewers conducted one-on-one interviews with female and male groups, respectively. We obtained written consent from the participants upon informing them about the purpose of the study. We held a total of 8 focus group interviews which lasted between 40 and 90 minutes. The interviews were recorded via a voice recorder upon the permissions of the participants. We ensured confidentiality during the interviews by using "numbers" assigned to the participants instead of their real names. In this study, we subjected the data to content analysis. Accordingly, two of the researchers carried out coding of the contents. Intercoder reliability was found to be .98 . Also, they coded the responses to the question about the prevention of dating violence as "Effective" and "Ineffective." For this coding process, intercoder reliability was found to be .90 . The researchers needed to come to a consensus on two statements.

\section{Findings}

In the study, where university students revealed their opinions on dating violence through the interview questions, the frequency of statements exceeded the number of participants $(n=78)$. The first question of the research was related to how the participants would define dating violence. However, the participants exemplified some behaviors in dating violence rather than defining it. Therefore, a small number of definitions $(n=$ 22) were elicited from the participants. The definitions obtained were like "Anything done without the consent of the partner," "Anything that can stress the partner out," "Not being able to respond to mutual requests," "It is rather the abuse of love." The responses to the second and third questions were evaluated together. The responses given to these questions were clustered under 5 categories of dating violence: physical $(9 \%, f=22)$, emotional $(72 \%, f=187)$, sexual $(17 \%, f=45)$, economic $(1 \%, f=2)$, and stalking $(1 \%, f=3)$. The responses to the fourth question revealed the participants' opinions on the characteristics of perpetrators. We found out that $77 \%(f=114)$ of the responses included individual, $14 \%$ $(f=20)$ included familial, and $9 \%(f=14)$ were related to contextual explanations. Meanwhile, the characteristics of the victims were determined by the responses to the fifth question. Eighty-five percent $(f=98)$ of the statements were included in individual, $4 \%(f=4)$ were considered in familial, and $12 \%(f=16)$ were included in contextual aspects. In response to the sixth question, the participants produced solutions for what could be done after exposure to dating violence. The responses were in the categories of inability to do anything $(28 \%, f=18)$, ending the relationship $(25 \%, f=16)$, making decisions by the intensity of violence $(22 \%, f=14)$, taking action to solve the problem $(11 \%, f=7)$, doing the same to the perpetrator $(9 \%, f=6)$, reporting to authorities $(3 \%, f$ $=18)$, and giving emotional reactions $(2 \%, f=1)$. The seventh question of the study allowed the participants to talk about the causes of dating violence. The responses were related to individual reasons $(42 \%, f=47)$, familial reasons $(2 \%, f=3)$, contextual reasons $(50 \%, f=56)$, cycle of violence $(4 \%, f=4)$, and avoidance of greater problems $(2 \%, f=3)$. The eighth question of the study was about people with whom the victims can share their dating violence experiences. The participants stated that they could share their such experiences with their friends $(38 \%)$, families $(32 \%)$, and partners $(8 \%)$, a specialist $(3 \%)$, everybody $(1 \%)$, and unbiased people $(1 \%)$. While $12 \%$ of the participants stated that they would not tell anyone about their dating violence experiences, 5\% expressed that family members would never be informed about such experiences. We examined the reasons for not sharing such experiences through the responses to the ninth question. While $58 \%(f=15)$ stated that they were afraid of negative reactions, $30 \%(f=8)$ pointed out selfblame. In addition, $8 \%(f=2)$ thought that their relatives could be biased towards them, and $4 \%(f=1)$ stated that there was nobody around to share such experiences. The last question of the study was related to the prevention strategies. The categories were classified as effective and ineffective. Although few of the participants $(f=3)$ stated that dating violence could not be prevented, almost all proposed individual $(34 \%, f=36)$, familial $(8 \%, f=$ $8)$, and contextual $(58 \%, f=62)$ prevention strategies. Whereas $69 \%$ of individual interventions $(f=25)$ were classified as "Effective," $31 \%(f=11)$ were deemed to be "Ineffective." All of the familial and $85 \%$ of contextual interventions $(f=53)$ were considered "Effective," but $15 \%$ of contextual interventions $(f=9)$ were classified as "Ineffective."

\section{Discussion}

This study aimed to reveal an in-depth understanding of the perceptions, attitudes, and experiences of university students concerning dating violence. The results 
showed that the participants uttered examples of emotional dating violence more than other types of dating violence, which may be explained with some possible reasons. First, considering the sociocultural structure of Turkey, the fact that sexuality is still a taboo may have prevented the participants from talking about sexual violence. Also, we thought that university students might abstain from talking about physical and sexual violence in front of others. Although we formed the study groups with students from different departments and unfamiliar with each other, they might remain reluctant to talk about such issues. We also discovered that the participants talked the least frequently about stalking and economic violence, which is consistent with previous findings. Other studies suggested that stalking and economic violence were reported less among the participants than other types of violence (Niolon et al., 2015; Sünetçi et al., 2016). The participants were more likely to get support from their friends and families after exposed to dating violence. A study by Martin et al., (2013) concluded that those exposed to dating violence sought help from informal sources, such as peers and family, rather than professionals. However, some of the responses were related to staying silent about such experiences. Ashley and Foshee (2005) discovered that the majority of the participants did not want to seek help after experiencing dating violence. As a continuation of this problem, we sought to uncover the reasons for not sharing their dating violence experiences. The themes that emerged based on their responses were fear of undesirable reactions, selfblame, biased attitudes of relatives, and having nobody around to share such experiences, respectively. Similar to the findings of this study, previous research concluded that adolescents and university students faced many obstacles in seeking help for dating violence, such as feeling shame, lack of information about the support sources, fear of stigma, and privacy concerns (Ashley \& Foshee, 2005; Martin et al., 2013). Consequently, it is essential to inform the population about dating violence. Furthermore, the participants noted individual, familial, and contextual risk factors for dating violence. It is widely known that there is no single cause of violence but that it shows up due to the accumulation of multiple individual, familial, and contextual risk factors (Cicchetti \& Lynch, 1993).

This study has some considerable strengths. This study was the first to address the definition of dating violence among university students, types of dating violence, the students' experiences of dating violence, causes of violence, methods of coping with dating violence, and prevention strategies. In the study, eight focus group interviews with 78 participants enhanced the heterogeneity of the sample. In addition, the number of focus group interviews contributed to the validity and reliability of the research. Conducting focus group interviews can also be considered a strength of the study in providing a dynamic and interactive environment. Another strength of this research is that the interviewers and participants were of the same gender in the interviews, allowing the participants to share reliable and candid information. However, this study has some limitations. Firstly, conducting focus group interviews can also be considered a limitation of this study. Although we carefully formed the groups where the participants did not know each other, some students may have been affected by the grouping process and did not provide accurate information. Secondly, the findings of this study were only based on the experiences of university students. Further studies may replicate the research with a different sample. Thirdly, we did not regard whether the participants exerted or were exposed to dating violence before. Future research can be conducted only with university students who were subjected to dating violence or perpetrators of dating violence. Dating violence is a prevalent problem with adverse effects on individuals; hence, its recognition is critical among academics, specialists, teachers, and policymakers. Finally, there is a need more for prevention and intervention studies to be conducted in Turkey. 